\title{
Light and Electron Microscopic Demonstration of D-Mannose and D-Glucose Like Sites at the Cell Surface by Means of the Lectin from the Lens culinaris
}

Lectins are 'naturally occuring' antibody-like substances which may react with various simple sugars in an immunologically specific way. By use of wheat germ agglutinin, Concanavalin A, soy bean agglutinin and Ricinus communis agglutinin, differences in the cell surface architecture between normal and malignant cells could be demonstrated in agglutination experiments (for review see 1 ). Concanavalin $A$ has been repeatedly utilized in electron microscopic studies for the visualization of cell coat components ${ }^{2}$ and of differences of these in normal and malignant cells as well ${ }^{3-5}$. Recently, wheat germ agglutinin has been used for electron microscopic demonstration of $\mathrm{N}$-acetyl-D-glucosamine like sites at the cell surface ${ }^{6}$.

The lectin from the Lens culinaris (LcH) reacts immunologically specifically with D-mannose and $D$ glucose like sites ${ }^{7,8}$. We introduced this lectin for light and electron microscopic cytochemical studies on Ehrlich ascites carcinoma cells, rabbit erythrocytes and various tissues. In this paper we shall report our observations on Ehrlich ascites carcinoma cells (EAC).

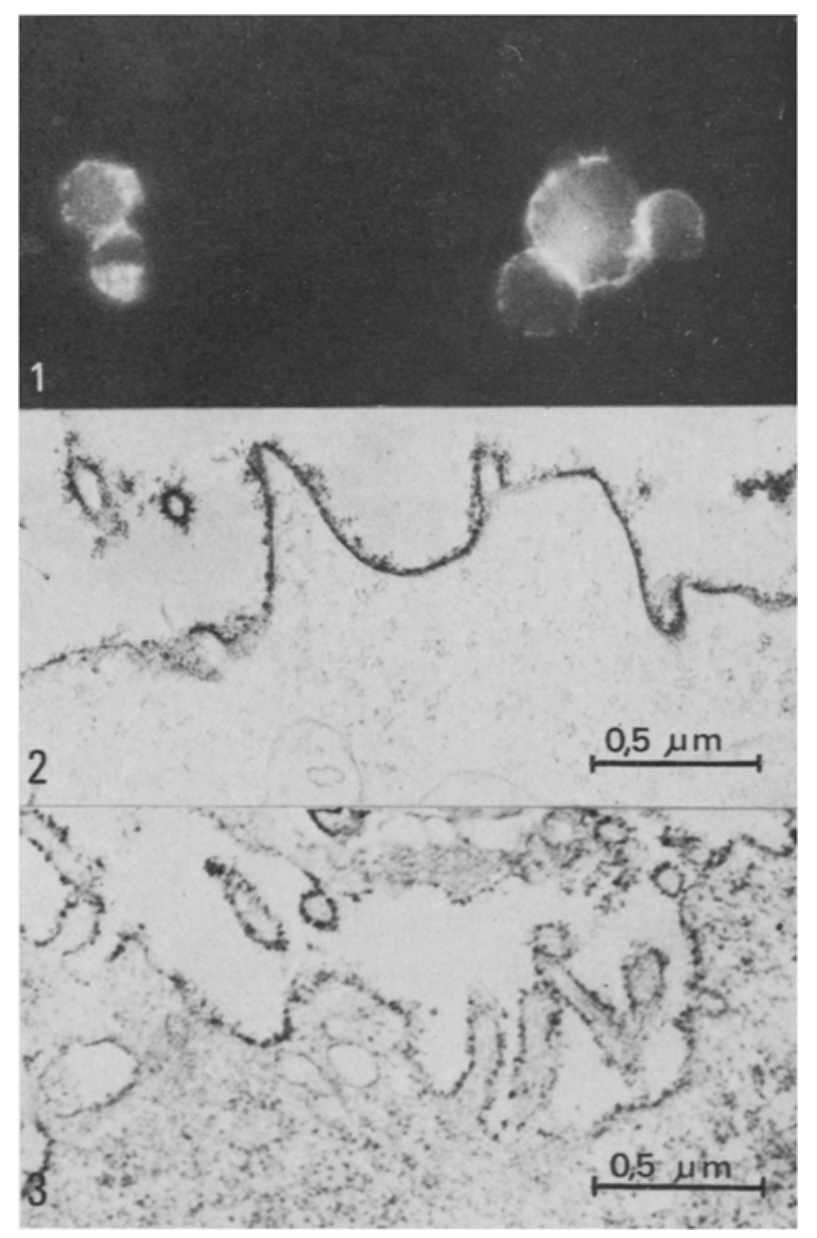

Fig. 1. Ehrlich ascites carcinoma cells stained with LcH-FITC. Spotlike fluorescence in the cell surface. $\times 500$.

Fig. 2. Ehrlich ascites carcinoma cell with positive LcH-peroxidase reaction in the cell surface. $\times 30.000$.

Fig. 3. Ehrlich ascites carcinoma cell. Staining of cell coat components by peroxidase labeled LcH. $\times 30,000$.
The purification of LcH was performed by combination of the methods of HowARD and $\mathrm{SAGE}^{7}$ and that of Toxosyima et al. ${ }^{2}$. The lyophilized $\mathrm{LcH}$ shows a strong agglutination of rabbit erythrocytes up to concentration of $5 \mathrm{ug} / \mathrm{ml}$. Coupling of $\mathrm{LcH}$ with fluoresceine isothiocyanate (FITC) was performed by use of $2 \%$ FITC following separation of the dye excess by Sephadex G-25.

Living $E A C$ cells were incubated at room temperature or at $4^{\circ} \mathrm{C}$ for $30 \mathrm{~min}$. After rinsing they were placed on glass slides. The electron microscopic visualization of the LcH binding sites at the cell surface was effectuated by incubation of the cells in LcH followed by incubation in horseradish peroxidase (LcH-Po reaction) as well as by incubation in peroxidase labelled LcH. For the peroxidase labelling of $\mathrm{LcH}$, the two step technique of AVRAMEAs and TERNYNCK ${ }^{10}$ was used. In both experiments the peroxidase activity was demonstrated by the diaminobenzidine reaction. Living EAC cells, as well as glutaraldehyde prefixed ones, were incubated at room temperature or at $4^{\circ} \mathrm{C}$ for $15 \mathrm{~min}$. By use of LcH-FITC (concentrations between $1 \mathrm{mg} / \mathrm{ml}$ and $5 \mu \mathrm{g} / \mathrm{ml}$ ) a ring fluorescence with small gaps could be observed at the cell surface (Figure 1). The surface fluorescence could be decreased or suppressed by addition of the haptens (0.01-0.2 $M$ D-mannose or a-methyl-D-glucopyranoside). Following the LcH-Po reaction $(100 \mu \mathrm{g} \mathrm{LcH} / \mathrm{ml})$, an electron dense precipitate varying in thickness was seen at the cell surface (Figure 2). There is no positive reaction in the intracellular structures. Similar results were obtained by use of peroxidase labelled LcH (Figure 3). The precipitate layer was likewise varying in thickness; however, in general, it was thinner than in the LcH-Po reaction. In the control experiments, the reaction was negative. The results will soon be published in detail.

Zusammenfassung. Es wird über die Verwendung des Lektins von Lens culinavis zum immunologisch-spezifischen licht- und elektronenmikroskopischen Nachweis von D-Mannose- und D-Glukose-artigen Orten der Zelloberfläche berichtet.

\section{J. RoTH and K. Thoss}

Institute of Pathology, Friedrich-Schiller-University, Jena DDR-69 Jena (German Democratic Republic), 19 October 1973.

1 N. SHARon and H. Lis, Science 177,949 (1972).

2 W. Bernhard and A. Avrameas, Expl Cell Res. 64, 232 (1971).

${ }^{3}$ A. Martinez-Palomo, R. Wicker and W. Bernatiod, Int. J. Cancer 9, 676 (1972)

4 G. L. Nicolson, Nature New Biol. 233, 244 (1971).

5 J. Roth, H. W. Meyer, G. Neupert and F. Bolck, Exp. Path. 8 19 (1973).

${ }^{6}$ Ch. Huet and J. Garrido, Expl Cell Res. 75, 523 (1972).

7 J. K. HowARD and H. J. SAGE, Biochemistry 8, 2436 (1969).

8 N. H. Yourg, M. A. Leon, T. TAkafashi, J. K. Howard and H. J. SAGE, J. biol. Chem. 246, 1596 (1971).

${ }^{3} \mathrm{~S}$. Toyoshima, T. Osawa and A. Tonomura, Biochim. biophys. Acta 221,514 (1970).

10 A. Avrameas and T. TERnYNCK, Immunochemistry 8,1175 (1971). 